\title{
Partisipasi Guru dan Orangtua Dalam Usaha Pencegahan Penularan
}

\section{Covid-19}

\author{
Emyranda Samosir
}

emyrandasamosir@gmail.com

\begin{abstract}
ABSTRAK
Pandemi COVID-19 mempengaruhi hampir semua aspek kehidupan, tak terkecuali aspek pendidikan.Pada kondisi pandemi peran dan posisi aspek pendidikan adalah sangat krusial . Untuk memutus mata rantai penyebaran COVID-19-dimana siswa dapat berperan sebagai pembawa dan penyebar penyakit tanpa gejala-hampir semua negara meniadakan kegiatan di sekolah. Hingga April 2020, lebih dari 400 juta siswa di dunia diwajibkan untuk belajar di rumah. Konsekuensi dari penutupan Lembaga Pendidikan secara fisik dan mengganti dengan belajar di/dari rumah sebagaimana kebijakan pemerintah adalah adanya perubahan system belajar mengajar (Arora \& Srinivasan, 2020). Pengelola sekolah, siswa, orang tua, dan tentu saja guru harus bermigrasi ke sistem pembelajaran digital atau online, yang lebih dikenal dengan istilah e-learning (Aderholt, 2020; Karp \& McGowan, 2020; UNESCO, 2020a) atau dikenal dengan istilah pembelajaran dalam jaringan atau "pembelajaran daring" di Indonesia. Secara serempak, mayoritas lembaga pendidikan memilih opsi pembelajaran daring (Azzi-Huck \& Shmis, 2020;

Orang tua sangat berperan penting dalam pencegahan penularan covid-19. peran orang tua dalam mencegah Covid-19 adalah dengan menjaga dan memastikan seluruh anggota keluarga untuk menerapkan pola hidup bersih dan sehat di masa pandemic Covid-19. Orang tua yang selalu memberi perhatian pada anaknya, terutama perhatian pada kegiatan belajar mereka dirumah, akan membuat anak lebih giat dan lebih bersemangat dalam belajar karena ia tahu bahwa bukan dirinya sendiri saja yang berkeinginan untuk maju, akan tetapi orang tuanya juga memiliki keinginan yang sama. Sehingga hasil belajar atau prestasi belajar yang diraih oleh siswa menjadi lebih baik.
\end{abstract}

Kata kunci :guru, orang tua, pencegahan, covid-19 


\section{LATAR BELAKANG}

\section{Coronavirus Disease 2019 atau} COVID-19 telah menginfeksi jutaan orang di lebih dari 200 negara di dunia dan menyebabkan banyak kematian (Khan et al., 2020; Lin et al., 2020; Worldometers, 2020). Penyakit yang disebabkan oleh Severe Acute Resviratory Syndrome- Coronavirus 2 atau SARS-CoV-2 ini pertama kali dilaporkan di Kota Wuhan Provinsi Hubei, China.World Health Organisation (WHO) telah menetapkan COVID-19 sebagai pandemi global.Sejak akhir tahun 2019, dunia telah digemparkan dengan kemunculan Corona Virus Disease 19 atau dikenal dengan COVID-19, di Kota Wuhan, China. Covid-19 yang membuat kehidupan manusia lumpuh di berbagai sector, mulai dari sektor perekonomian sampai dengan sektor pendidikan. Virus ini mulai masuk ke Indonesia sejak awal tahun 2020 dan menyebar secara masif pada Maret 2020.

Dari kasus-kasus yang muncul pemerintah Indonesia banyak mengambil kebijakan-kebijakan sebagai upaya memutuskan rantai penyebaran COVID-19. Pemerintah memutuskan untuk melakukan lockdown wilayah, penghentian segala aktivitas di luar rumah termasuk proses belajar di sekolah. Menurut data Organisasi Pendidikan, Keilmuan, dan Kebudayaan
PBB (UNESCO), setidaknya ada 290,5 juta siswa di seluruh dunia yang aktivitas belajarnya menjadi terganggu akibat sekolah yang ditutup (Smith \& Jones, 2004).

Untuk itu, di tengah Covid-19 yang menjadikan keluarga sebagai pusat aktivitas, orang tua harus kembali lebih menyadari peran pentingnya dalam pendidikan anak usia remaja. Tugas-tugas sebagai pembimbing, pendidik, pengasuh, pemelihara serta juga bisa menjadi guru bagi anak perlu dikuatkan (Ahmadi \& Uhbiyati, 2015). Hal ini juga sangat berdampak terhadap sukses atau tidaknya anak dalam belajar selama di Rumah. Orang tua yang selalu memberi perhatian pada anaknya, terutama perhatian pada kegiatan belajar mereka dirumah, akan membuat anak lebih giat dan lebih bersemangat dalam belajar karena ia tahu bahwa bukan dirinya sendiri saja yang berkeinginan untuk maju, akan tetapi orang tuanya juga memiliki keinginan yang sama. Sehingga hasil belajar atau prestasi belajar yang diraih oleh siswa menjadi lebih baik.Peran orang tua juga sangat diperlukan utuk memberikan edukasi kepada anak anaknya yang masih belum bisa memahami tentang pandemi yang sedang mewabah untuk tetap berdiam diri dirumah agar tidak terlular dan menularkan wabah pandemi ini. Peran orang tua dalam situasi pandemi 
Covid-19 ini memiliki kedudukan yang fundamental.

\section{METODE}

Metode dalam penulisan ini menggunakan metode kualitatif, yaitu merupakan metode yang sifatnya memberikan suatu penjelasan dengan analisis. Metode ini bersifat subjektif, yaitu proses penelitian yang lebih fokus pada landasan teori. Metode yang digunakan dalam kajian ini adalah Literature review. Metode ini menganalisis, eksplorasi dan kajian bebas pada artikel, jurnal, maupun ebook yang releven dan berfokus pada peran orangtua sebagai bagian dari pencegahan penulaaran covid-19 inis. Adapun artikel yang digunakan pada literature review ini adalah artikel yang didapatkan dengan memuat 3 database Pubmed, Geogle Scholar dan Science Direct.

\section{HASIL}

Dunia sedang berjuang melawan COVID-19, lembaga pendidikan harus cepat melakukan antisipasi (Snelling \& Fingal, 2020). Sebagaimana yang dilakukan pada pandemi influenza, praktek yang paling sering diterapkan oleh sekolah adalah membatalkan atau menunda kegiatan pembelajaran di sekolah, membatalkan kelas atau kegiatan dengan tingkat pencampuran/kontak yang tinggi yang terjadi dalam jam belajar, dan mengurangi interaksi fisik selama menggunakan alat transportasi (Uscher-Pines et al., 2018). Lembaga pendidikan di dunia harus ditutup sementara, mengikuti instruksi pemerintah di negara masing-masing, sehingga mempengaruhi sistem akademik. Mereka harus menemukan alternatif baru untuk melaksanakan pembelajaran,dan kelas virtual/pembelajaran daring adalah jalan ke depan yang paling mungkin dilakukan..

(Arora \& Srinivasan, 2020).

Bagaimanapun, kompetensi guru juga menjadi penentu utama keberhasilan pencegahan COVID 19 dalam proses pembelajaran, termasuk di Indonesia. Guru akan berusaha sedapat mungkin agar kegiatan pembelajaran yang dilakukan berhasil. Guru berperan sebagai pengorganisasi lingkungan belajar dan sekaligus sebagai fasilitator belajar. Untuk memenuhi itu, maka guru haruslah memenuhi aspek bahwa guru sebagai: model, perencana, peramal, pemimpin, dan penunjuk jalan atau pembimbing ke arah pusat-pusat belajar. Guru berperan untuk mengarahkan dan memberikan fasilitas belajar kepada 
peserta didik (directing and facilitating the learning) agar proses belajar

berjalan secara memadai, tidak semata-mata memberikan informasi (Zein, 2016). Bagaimana dan apapun bentuk strategi, model, dan media pembelajaran yang digunakan guru, sejatinya diorientasikan pada satu syarat utama, yaitu menarik sehingga menumbuhkan minat belajar siswa (Abdullah, 2016). Hal ini juga berlaku di masa pandemi COVID-19.

Tak hanya Guru, keluarga menjadi pilar penting dalam menjaga anak-anak maupun anggota keluarga dari bahaya Virus Corona dengan melakukan berbagai upayaupaya yang kreatif dan inovatif. Pandemi Covid-19 bisa menjadi wadah yang dapat memberikan kesadaran bagi keluarga agar semakin mendekatkan diri dengan keluarga. Berbagai kegiatan yang dapat dilakukan orang tua dalam masa pandemi, yaitu mendampingi anak belajar, beribadah bersama serta melibatkan anak dalam melakukan kegiatan selama dirumah. Berbagai upaya yang bisa dilakukan orangtua dalam mencegah penyebaran Covid-19 yaitu membiasakan disiplin bagi anggota keluarga agar menjaga protokol kesehatan dan menjaga kebersihan diri agar tetap sehat serta terhindar dari penularan covid-19. Selain itu, tindakan lain yang bisa dilakukan dengan memberikan contoh ketika keluar luar dengan selalu menggunakan masker, membatasi jarak komunikasi, maupun tidak kontak secara langsung. Berbicara tentang orang tua tidak terlepas dari peran keluarga, yaitu yang menjaga anak baik fisik maupun psikis atau memberi dukungan emosi dan materi, serta pemenuhan peranan tertentu. Pengawasan dan perlindungan anak adalah suatu kegiatan berkelanjutan melalui proses interaksi agar anak berkembang secara optimal dan sehat baik jasmani maupun rohani.

\section{PEMBAHASAN}

Munculnya COVID-19 berfungsi untuk mengingatkan kita di semua lintas disiplin yang berbeda bahwa kita selalu harus siap dengan mengikuti pendekatan semuabahaya (all-hazards approach). Pentingnya kemitraan publik dan pribadi yang berkelanjutan tidak cukup hanya ditekankan. Kita akan melewati COVID-19 dengan menerapkan komunikasi, kolaborasi, kerja sama, dan koordinasi yang baik (Contreras, 2020).

Dalam konteks pembelajaran daring, tentu apresiasi layak diberikan kepada guru, sekolah, peserta didik, dan bahkan orang tua/wali murid karena mereka mampu 
beradaptasi dengan cepat. Namun, seiring berjalannya waktu semua pihak perlu mengevaluasi pembelajaran daring tersebut agar tujuannya bisa tercapai secara optimal. Beban belajar peserta didik harus logis dan terukur. Banyaknya tugas atau tagihan yang diberikan guru menjadi keluhan umum dalam pembelajaran daring. Beban belajar peserta didik tentunya harus diperhitungkan, terukur, baik secara materi maupun waktu. Guru dapat memberikan yang lebih menantang dan menarik, misalnya mengamati, mencoba, dan menganalis. Dalam pembelajaran daring punmeskipun dilakukan secara jarak jauhsapaan, respon, umpan balik, penghargaan terhadap hasil pekerjaan peserta tidak boleh terlupakan. Jangan sampai muncul anggapan bahwa peserta didik seakan diperdaya karena tugas yang sangat banyak, tidak logis, dan tanpa umpan balik. Jangan sampai pekerjaan yang sudah dikerjakan maksimal oleh peserta didik, tetapi guru tidak mengoreksi

(Anugrah, 2020).

Lebih lanjut menurut Anugrah (2020), apresiasi terhadap capaian siswa perlu diberikan guru agar tujuan pembelajaran bisa tercapai. Salah satu tujuan pembelajaran termasuk dalam hal ini pembelajaran daring adalah pencapaian kompetensi peserta didik yang dikenal dengan 4C, yaitu (1) critical thinking (berpikir kritis) yang mengarahkan peserta didik untuk untuk dapat menyelesaikan masalah (problem solving); (2) creativity thinking (berpikir kreatif) dapat dimaknai guru dapat mendampingi peserta didik yang memiliki kreativitas tinggi mampu berpikir dan melihat suatu masalah dari berbagai sisi atau perspektif; (3) collaboration (bekerja sama atau berkolaborasi) agar peserta didik mampu dan siap untuk bekerja sama dengan siapasaja dalam kehidupannya mendatang; dan (4) communication (berkomunikasi) dapat dimaknai sebagai kemampuan peserta didik dalam menyampaikan ide dan pikirannya secara cepat, jelas, dan efektif.

Pembelajaran daring dikembangkan untuk mewujudkan sistem pendidikan terpadu yang dapat membangun konektivitas antar komponen yang ada dalam Pendidikan. Oleh karenanya pendidikan menjadi lebih dinamis dan fleksibel bergerak untuk pengembangan pendidikan. Sudah barang tentu semua ini harus diikuti oleh kesiapan seluruh komponen sumber daya manusia baik dalam cara berpikir, orientasi, perilaku, sikap, dan sistem nilai yang mendukung pemanfaatan pembelajaran daring untuk kemaslahatan umat manusia. Selain itu, akses ke jaringan internet juga harus disediakan. Seorang pengguna bisa berhubungan dengan internet dengan mengakses komputer pada 
lembaga pendidikan yang telah terkoneksi ke internet atau perlu menjadi pelanggan dari sebuah ISP (internet service provider). ISP adalah organisasi komersial yang bergerak dalam bidang penyediaan jasa akses ke internet. Bisa juga melakukan pengaksesan pada warung internet (Munir, 2017). Hal inilah yang harus dipikirkan oleh penyelenggara pendidikan, khususnya pemerintah.

Terkait pembelajaran daring, meyakinkan peserta didik dan orang tua adalah elemen vital dari respons institusional (guru dan sekolah). Sebagai upaya meningkatkan kapasitas untuk pembelajaran daring, sekolah harus memanfaatkan kondisi asinkron. Seperti halnya pelajaran kelas normal, pembelajaran daring harus mencakup berbagai tugas dan pekerjaan yang menempatkan COVID-19 dalam konteks global dan historis. Saat memutuskan implementasi pembelajaran daring, harus dirancang penilaian yang membantu guru untuk fokus. Sudut pandang ini menyarankan cara-cara yang fleksibel untuk menutupi kekurangan system pembelajaran sampai pandemi berakhir (Daniel, 2020).

Sementara itu, Snelling dan Fingal (2020) memaparkan bahwa International Society for Technology in Education (ISTE) di Amerika Serkat telah berupaya mengidentifikasi praktik praktik utama untuk pembelajaran daring yang sukses. Berikut adalah beberapa ide terbaik dari pendidik dari seluruh dunia, banyak dari mereka telah mengajar selama pandemi COVID-19. Pertama, "mempersiapkan dan berlatih". Ada lima hal yang harus diperhatikan, yaitu (1) pastikan ekuitas digital. Kesetaraan adalah hambatan terbesar dalam mempersiapkan pembelajaran daring, dan inilah hal pertama yang harus dipikirkan guru. Guru dan seklah perlu memastikan bahwa semua peserta yang terlibat memiliki perangkat. Itulah mengapa perlu dilakukan survei atau pendataan guru dan keluarga untuk mengetahui siapa yang akan membutuhkan perangkat daring dan paket data (bandwidth). Selama penutupan sekolah, orang tua mungkin juga bekerja dari rumah, yang berarti beberapa orang dapat bersaing untuk satu-dua computer atau sarana daring. Karena itu, pastikan semua aplikasi daring berfungsi pada perangkat seluler seandainya laptop tidak tersedia. Untuk guru atau siswa yang tidak memiliki Wi-Fi di rumah, pemerintah sejatinya harus mencari cara untuk membeli atau menyewa hotspot $W i-F i$ dan kemudian memiliki rencana untuk mendistribusikan perangkat daring dan hotspot. (2) Berlatih. Sekolah yang sudah terbiasa melaksanakan pembelajaran daring, tentu tidak lagi melalui kendala konektivitas 
dengan peserta didik di rumah dan masalah perangkat. Tetapi bagi sekolah yang belum memiliki pengalaman atau masih pada level dasar, sehrusnya momentum ini dianggap sebagai peluang. Guru belum menggunakan sistem manajemen pembelajaran secara teratur, perlu belajar sekarang dan cepat sehingga tidak akan ada gangguan dalam komunikasi setelah adanya kebijakan penutupan aktivitas di sekolah. Guru harus melatih diri dan peserta didik mereka tentang aplikasi dan teknologi yang mungkin perlu mereka gunakan saat belajar di/dari rumah. Berlatih di kelas/sekolah dan kemudian meminta pesert didik untuk mencoba menggunakan alat alat dari rumah. (3) Berikan harapan yang jelas kepada staf dan orang tua. Selama kegiatan pembelajaran daring, komunikasi antara administrator, staf, orang tua dan peserta didik lebih penting dari sebelumnya. Untuk komunikasi gambar besar, siapkan FAQ yang menguraikan semua detail tentang bagaimana sekolah akan beroperasi selama penutupan sehingga staf dan orang tua dapat mengakses website atau fasilitas daring yang sama. Untuk komunikasi gambar besar, siapkan FAQ yang menguraikan semua detail tentang bagaimana sekolah akan beroperasi selama penutupan sehingga staf dan orang tua ada di halaman yang sama. Selain memposting dan mendistribusikan FAQ, sekolah-sekolah harus mengatur SMS di seluruh komunitas untuk berkomunikasi dengan cepat dan kemudian memberi tahu orang-orang di mana menemukan pesan tindak lanjut melalui $e$ mail atau website. Selanjutnya, siapkan panduan langkah demi langkah tentang cara mengakses dan menggunakan alat dan kurikulum pembelajaran daring.

Pastikan Anda menyajikan informasi ini dalam berbagai format termasuk video dan teks dan termasuk screenshot dan tutorial. Mintalah orang tua untuk memastikan semua peserta didik - terutama yang masih anak-anak - tahu cara masuk ke aplikasi dan mengetahui kata sandi mereka.. Para guru perlu mengetahui cara login dan menggunakan fasilitas. Berikan dukungan teknis ekstra dan pastikan orang tua dan guru tahu cara meminta bantuan bila diperlukan. (4) Luangkan waktu untuk merencanakan. Jika penutupan sekolah terjadi sebelum semua guru siap untuk melaksanakan pembelajaran daring, maka luangkan waktu bahkan jika itu hanya satu atau dua hari untuk bersiap sebelum meluncurkan sistem pembelajaran daring dengan siswa. Penundaan sementara dalam memulai pembelajaran daring akan terbayar dalam jangka panjang. (5) Siapkan kebutuhan pribadi, lengkapi sarana-prasarana. Pastikan 
Anda memiliki akses ke semua yang Anda butuhkan dari rumah jika Anda tidak dapat kembali ke sekolah atau membawa pulang komputer yang sering digunakan di sekolah Anda dan memindahkan file Anda ke Cloud.

Sedangkan Peran orang tua di rumah bersifat edukatif dengan memberikan segala bentuk pembelajaran baik verbal maupun nonverbal yang gunakanya anak akan semakin optimal dan kebutuhannya tercukupi sehingga anak tersebut menjadi anak yang mandiri, berkompeten, dan disiplin. Adapun tindakan yang bisa dilakukan oleh orangtua di rumah dengan cara membuat jadwal pembelajaran, mengawasi, membiasakan hidup bersih sehingga anak timbul kesadaran untuk melakukan tindakan yang baik yang sesuai dengan aturan yang berlaku. Orang tua memiliki tanggung jawab utama dalam proses pertumbuhan dan perkembangan anaknya, baik atau buruknya didikan yang diberikan orang tua akan berpengaruh terhadap perkembangan dan pertumbuhan anak itu sendiri. Menurut Widayati (2018) menjelaskan bahwa peran orang tua dalam keluarga terdiri dari:

$\checkmark$ Peran sebagai pendidik, orang tua perlu menanamkan kepada anak-anak arti penting pendidikan dan ilmu pengetahuan yang mereka dapatkan dari sekolah. $\checkmark$ Peran sebagai pendorong, sebagai anak yang sedang menghadapi masa peralihan, anak membutuhkan dorongan orang tua untuk menumbuhkan keberanian dan rasa percaya diri dalam menghadapi masalah.

$\checkmark$ Peran sebagai panutan, orang tua perlu memberikan contoh dan teladan bagi anak, baik dalam berkata jujur maupun dalam menjalankan kehidupan sehari-hari dan bermasyarakat.

$\checkmark$ Peran sebagai teman, menghadapi anak yang sedang menghadapi masa peralihan. Orang tua lebih sabar dan mengerti tentang perubahan anak. Orang tua dapat menjadi informasi, teman bicara atau teman bertukar pikiran tentang kesulitan atau masalah anak, sehingga anak merasa nyaman dan terlindungi.

$\checkmark$ Peran sebagai pengawas, kewajiban orang tua adalah melihat dan mengawasi sikap dan perilaku anak agar tidak keluar jauh dari jati dirinya, terutama dari pengaruh lingkungan baik dari lingkungan keluarga, sekolah dan masyarakat.

$\checkmark$ Peran sebagai konselor, orang tua dapat memberikan gambaran dan 
pertimbangan nilai positif dan negatif sehingga anak mampu mengambil keputusan yang terbaik.

\section{KESIMPULAN}

Sekolah dan guru melaksanakan kebijakan pemerintah untuk belajar dari rumah sebagai upaya memperlambat penyebaran COVID-19 namun sekaligus tetap memastikan peserta didik dalam kegiatan konstruktif melalui pembelajaran daring. Berbagai flatform digunakan dalam pembelajaran daring, sementara guru, peserta didik, dan orang tua diharapkan terus melakukan penyesuaian seiring berjalannya waktu. Berbagai respon positif disampaikan peserta didik terkait pembelajaran daring karena dirasa lebih santai, menyenangkan, fleksibel, efisien, singkat, praktis, cepat, tepat, aman, mudah, hemat waktu, dan hemat tenaga. Pembelajaran dapat dilakukan secara jarak jauh, orang tua bisa mengawasi anakanaknya belajar, membuat peserta didik menjadi melek teknologi, dan lebih kreatif. Sebagai rekomendasi ke depan, yang dibutuhkan adalah kemitraan publik dan banyak pihak yang berkelanjutan. Dibutuhkan adanya komunikasi, kolaborasi, kerja sama, dan koordinasi yang baik. Kompetensi guru menjadi penentu utama keberhasilan proses pembelajaran daring sehingga mereka harus terus memperkaya kompetensi dan keterampilan dan didukung oleh kebijakan sekolah yang mendorong mereka terus belajar. Pihak terkait juga perlu mengevaluasi pembelajaran daring tersebut agar tujuannya bisa tercapai secara optimal. Beban belajar peserta didik harus logis dan terukur. Beban belajar peserta didik tentunya harus diperhitungkan, terukur, baik secara materi maupun waktu. Guru tidak boleh semata-mata memberikan tugas, tetapi harus memperhitungkan secara matang. Guru tidak boleh lupa untuk mengapresiasi capaian peserta didik perlu diberikan guru agar tujuan pembelajaran bisa tercapai. Hal lain yang tidak kalah pentingnya dalam pembelajaran daring ke depan adalah adanya kurikulum yang fleksibel dan siap menghadapi pandemi.Peranan orang tua dalam upaya pencegahan penularan covid-19 ini sangat penting. Karena peran orang tua di rumah bersifat edukatif dengan memberikan segala bentuk pembelajaran baik verbal maupun nonverbal yang gunakanya anak akan semakin optimal dan kebutuhannya tercukupi sehingga anak tersebut menjadi anak yang mandiri, berkompeten, dan disiplin. Adapun tindakan yang bisa dilakukan oleh orangtua di rumah dengan cara membuat jadwal pembelajaran, mengawasi, membiasakan 
hidup bersih sehingga anak timbul kesadaran untuk melakukan tindakan yang baik yang sesuai dengan aturan yang berlaku.

\section{Daftar Pustaka}

Arora, A. K., \& Srinivasan, R. (2020). Impact of pandemic COVID-19 on the teaching learning process: A study of higher education teachers. Prabadhan: Indian Journal of Management, 13(4). https://doi.org/10.17010/pijom/2020/v13i4/1 $\underline{51825}$

Asmayanti. Syarif, A. Laelasari, E. (2021). PERAN ORANGTUA PADA KELUARGA DALAM MENCEGAH COVID 19. EDUINOVASI. ISSN 2774-5058. 1(1). 102124

Collie, R. J., Shapka, J. D., \& Perry, N. E. (2011). Predicting teacher commitment: The impact of school climate and socialemotional learning. Psychology in the Schools, 48(10), 1034-1048.

https://doi.org/10.1002/pits.20611

Cahyati, N.Kusumah, R. (2020). Peran Orang Tua Dalam Menerapkan Pembelajaran Di Rumah Saat Pandemi Covid 19. Jurnal
Golden Age. E-ISSN : 2549-7367. 4(1). 152159.

Luthfi, E. (2020). Strategi Orang Tua dalam Mengajar dan Mendidik Anak dalam Pembelajaran At The Home Masa Pandemi Covid-19. STAINU Purworejo: JurnalAl_Athfal. E-ISSN::2615-482X. 3(1). 37-46.

Murni Kaddi, S. Lestari, P. Adrian, D. (2020). Komunikasi Keluarga Dalam Pencegahan Coronavirus Disease 2019. Jurnal Ilmu Komunikasi. 4(1). 63-74.

Prasasti, Dio Giovani. (2020, Maret 06). Retrieved fromhttps://www.liputan6.com/health/read/4 195275/unesco-penutupan-sekolah-akibatcovid-19-berdampak-pada-290-juta-pelajardi-dunia

Wahyono,et.al.(2020). Guru profesional di masa pandemi COVID-19: Review implementasi, tantangan, dan solusi Pembelajaran Daring.Jurnal Pendidikan Profesi Guru.1(1)

Wulandari,Indra Muirti.(2020).

$\begin{array}{lrr}\text { PERAN GURU } & \text { TERHADAP } \\ \text { MENGOPTIMALKAN } & \text { UNIT } \\ \text { KESEHATAN } & \text { SEKOLAH } & \text { UNTUK } \\ \text { MELAKUKAN } & \text { PENCEGAHAN } & \text { COVID- } \\ \text { 19.Jurnal Ilmu Pendidikan .2(1). } & \end{array}$

